"Acridine and quindoline oligomers linked through a 4-aminoproline backbone prefer Gquadruplex structures" Ferreira, R., Artali, R., Farrera-Sinfreu, J., Albericio, F., Royo, M., Eritja, R., Mazzini, S. Biochim. Biophys Acta, 1810(8), 769-776 (2011). doi: 10.1016/j.bbagen.2011.04.013

\title{
Acridine and quindoline oligomers linked through a 4-aminoproline backbone prefer G-quadruplex structures
}

\footnotetext{
Rubén Ferreira $^{a}$, Roberto Artali ${ }^{\mathrm{b}}$, Josep Farrera-Sinfreu ${ }^{\mathrm{c}}$, Fernando Albericio ${ }^{\mathrm{d}}$, Miriam Royo $^{c}$, Ramon Eritja ${ }^{a, *}$, Stefania Mazzini ${ }^{\mathrm{e}, *}$.

${ }^{a}$ Institute for Research in Biomedicine, IQAC-CSIC, CIBER-BBN Networking Centre on Bioengineering, Biomaterials and Nanomedicine, Baldiri Reixac 10, E-08028 Barcelona, Spain. (Email: ruben.ferreira@irbbarcelona.org, recgma@cid.csic.es)

${ }^{b}$ Faculty of Pharmacy, Istituto di Chimica Farmaceutica e Tossicologica "Pietro Pratesi", Università degli Studi di Milano, Via Mangiagalli, 25I-20133, Milano, Italy, (Email: roberto.artali@unimi.it)

${ }^{c}$ Combinatorial Chemistry Unit, Barcelona Science Park, CIBER-BBN Networking Centre on Bioengineering, Biomaterials and Nanomedicine, Baldiri Reixac 10, E-08028 Barcelona, Spain. (Email: mroyo@pcb.ub.cat)

${ }^{\mathrm{d}}$ Institute for Research in Biomedicine, University of Barcelona, CIBER-BBN Networking Centre on Bioengineering, Biomaterials and Nanomedicine, Baldiri Reixac 10, E-08028 Barcelona, Spain. (Email: albericio@irbbarcelona.org)

${ }^{\mathrm{e}}$ Dipartimento di Scienze Molecolari Agroalimentari, Università degli Studi di Milano, via Celoria 2, 20133 Milano, Italy, (Email: stefania.mazzini@unimi.it)
}

\section{Corresponding author:}

Dr. Stefania Mazzini

Dipartimento di Scienze Molecolari Agroalimentari

Università degli Studi di Milano

via Celoria 2, 20133 Milano, Italy

Tel.: 00390250316824

Fax: 00390250316801

Email: $\underline{\text { stefania.mazzini@unimi.it }}$ 


\section{Abstract}

Background: DNA-intercalating drugs are planar molecules with several fused aromatic rings that form stacks between DNA base pairs, reducing the opening and unwinding of the double helix. Recently, interest on intercalating agents has moved in the search for new ligands to G-quadruplex structures.

Methods: The DNA binding properties of 4-aminoproline oligomers functionalized with one, two or three units of acridine and/or quindoline have been analyzed by competitive dialysis. A $\mathrm{NMR} /$ molecular dynamics study was performed on G-quadruplex telomeric sequence and the 4aminoproline dimer carrying two quindolines. A model of the complex with the telomeric DNA quadruplex is described.

Results and conclusions: A selectivity of quindoline 4-aminoproline oligomers for G-quadruplex and triplex structures was observed, especially for those quadruplex sequences found in telomeres and in the promoter regions of c-myc and bcl-2 oncogenes. In this model the quindoline dimer is stabilized by $\pi-\pi$ stacking interactions between the aromatic rings of the ligand and the nucleobases of the telomeric sequence that are located above and below the molecule.

General significance: The results of this work can be used for the design of new molecules with high affinity to telomeres which may have anticancer properties.

Keywords: Oligonucleotides, acridine, quindoline, G-quadruplex, NMR, DNA-binding drugs.

\section{Introduction}

DNA-intercalating drugs are planar molecules formed by several fused aromatic rings that form stacks between DNA base pairs, thus reducing the opening and unwinding of the double helix. Each intercalating drug binds strongly to particular base pairs due to several interactions, ranging from van der Waals interactions to the formation of hydrogen bonds with adjacent nucleobases [1, 2]. The selectivity of intercalating drugs may be improved by linking several intercalating units. Various authors have described the synthesis of bis- or tris-intercalating drugs with promising activity and selectivity [3, 4].

Recently, interest on intercalating agents has moved in the search for new ligands to Gquadruplex structures [5]. This structure motif is formed by the planar association of four guanines in a cyclic Hoosgsteen hydrogen bonding tetrad. Guanine rich sequences are able to form G- 
quadruplex structures which have been found in telomeres [6] and in transcriptional regulatory regions of important oncogenes such as $c-m y c$, and $c$-kit, [7, 8]. Ligands that selectively bind and stabilize these structures have become interesting anticancer drugs [9]. G-quadruplex stabilization occurs in most of the cases by $\pi$ - $\pi$ stacking and electrostatic interaction. G-quadruplex ligands are normally planar aromatic molecules that are prone to stacking with G-tetrads [10]. Some of them are also positively charged or have hydrophilic groups to favour electrostatic interaction [11].

In previous papers we have described the preparation of sequence specific oligomers of DNA-intercalating drugs using protocols based on solid-phase synthesis in an attempt to facilitate the preparation of compounds with improved DNA-binding selectivity $[12,13]$. The preparation of several acridine oligomers linked through 2-aminoethylglycine units by solid-phase synthesis protocols was also described [14]. These compounds show a clear affinity for several DNA Gquadruplex structures. Here we describe the DNA-binding properties of a complete series of 4aminoproline oligomers carrying up to three units of acridine and quindoline molecules. Competitive dialysis experiments show a very high affinity of quindoline 4-aminoproline oligomers for G-quadruplex especially those quadruplex sequences found in the promoter regions of $c-m y c$ [15] and $b c l-2[16,17]$ oncogenes. A detailed NMR / molecular dynamics study was performed on G-quadruplex telomeric sequence and the dimer quindoline-quindoline which is the oligomer with higher affinity for quadruplexes. A model of the complex that explains the affinity of the quindoline dimer with the DNA quadruplex is described.

\section{Materials and Methods}

\subsection{Compounds}

(1) Acridine-9-carboxylic acid, (2) 2-(acridine-9-carboxamide) acetic acid, (3) 10HIndolo[3,2b]quinoline-11-carboxylic acid, (4) 2-(10H-Indolo[3,2b]quinoline-11-carboxamide) acetic acid and (5-18) acridine and quindoline 4-aminoproline backbone oligomers were synthesized according to published procedures [13]. Their formulas are shown in Fig. 1.

\subsection{Oligonucleotide Synthesis.}

All the standard phosphoroamidites and reagents for DNA synthesis were purchased from Applied Biosystems and from Link Technologies. The synthesis of the oligonucleotides was performed at 1 $\mu \mathrm{mol}$ scale on an Applied Biosystem DNA/RNA 3400 synthesizer by solid-phase 2cyanoethylphosphoroamidite chemistry. The following sequences were prepared: T20: d(5'-TTT TTT TTT TTT TTT TTT TT-3'), 24bclc: d(5'-CCC GCC CCC TTC CTC CCG CGC CCG-3'), 6- 
mer: d(5'-CGA TGC-3'), Dickerson: d(5'-CGC GAA TTC GCG-3'), ds26: d(5'-CAA TCG GAT CGA ATT CGA TCC GAT TG-3'), GA triplex : d(5'-GAA AGA GAG GAG GCC TTT TTG GAG GAG AAG-3') + d(5'-CCT CCT CTC TTT C-3'), TC triplex: d(5'- CCT CCT CTC TTT CCC TTT TTC TTT CTC TCC TCC-3') + d(5'- GAA AGA GAG GAG G-3'), TG4T: d(5'-TGG GGT-3'), TBA: d(5'- GGT TGG TGT GGT TGG-3'), HT24: d(5'- TAG GGT TAG GGT TAG GGT TAG GGT-3'), T2AG3: d(5'-TTA GGG-3'), 24bcl: d(5'- CGG GCG CGG GAG GAA GGG GGC GGG-3'), cmyc: d(5'- GGG GAG GGT GGG GAG GGT GGG GAA GGT GGG G-3'). The resulting oligonucleotides were purified by HPLC and desalted in a Sephadex (NAP-10) G25 column.

\subsection{Competitive Dialysis Assays.}

A total $200 \mathrm{~mL}$ of the dialysate solution containing $1 \mu \mathrm{M}$ compound was used for each competition dialysis assay. A volume of $1001 \mu \mathrm{L}$ at $50 \mu \mathrm{M}$ monomeric unit of each of oligonucleotide sequence was placed in dialysis unit. Potassium phosphate buffer containing $185 \mathrm{mM} \mathrm{NaCl}, 185 \mathrm{mM} \mathrm{KCl}, 2 \mathrm{mM} \mathrm{NaH}{ }_{2} \mathrm{PO} 4,1 \mathrm{mM} \mathrm{Na} \mathrm{EDTA}_{2}$ and $6 \mathrm{mM} \mathrm{Na}_{2} \mathrm{HPO}_{4}$ at pH 7 was used for all experiments.

The samples were allowed to equilibrate with continuous stirring at room temperature overnight. Dialysis samples were removed to an Eppendorf tube. In order to measure the compound entered in the dialysis unit, dialysis samples were degraded to liberate the derivate as described previously [14].

Finally, the fluorescence of each samples was measured ( $\lambda_{\mathrm{ex}}$ and $\lambda_{\mathrm{em}}$ were set to 252 and $435 \mathrm{~nm}$ in acridine derivates and 276 and $500 \mathrm{~nm}$ in quindoline derivates) and normalized for each compound.

\subsection{NMR Spectroscopy}

The NMR spectra were recorded by Bruker AV-600 spectrometer operating at a frequency of $600.10 \mathrm{MHz}$ for ${ }^{1} \mathrm{H}$. ${ }^{1} \mathrm{H}$ spectra were recorded at variable temperature ranging from $5^{\circ} \mathrm{C}$ to $75^{\circ} \mathrm{C}$. ${ }^{1} \mathrm{H}$ chemical shifts $(\delta)$ were measured in ppm and referenced to external DSS (2,2-dimethyl-2silapentane-5-sulfonate sodium salt) set at $0.00 \mathrm{ppm}$. Estimated accuracy for protons is within 0.02 ppm.

The samples for NMR measurements were dissolved in $500 \mu 1 \mathrm{H}_{2} \mathrm{O} / \mathrm{D}_{2} \mathrm{O}(9: 1)$ containing $25 \mathrm{mM}$ $\mathrm{KH}_{2} \mathrm{PO}_{4}, 150 \mathrm{mM} \mathrm{KCl}$ and $1 \mathrm{mM}$ EDTA (pH 6.7) for the quadruplex d(5'-TTA GGG-3') ${ }_{4}$ and containing $10 \mathrm{mM} \mathrm{KH} \mathrm{PO}_{4}, 70 \mathrm{mM} \mathrm{KCl}$ and $0.2 \mathrm{mM}$ EDTA ( $\mathrm{pH}$ 7.0) for the double helix d(5'CGA TCG-3' $)_{2}$. The final concentration of the oligonucleotide solutions ranged between 0.6-0.7 
$\mathrm{mM}$. A stock solution of $\mathbf{9}$ and $\mathbf{3}$ was prepared in DMSO- $\mathrm{d}_{6}$ at the concentration of 6 and $12.5 \mathrm{mM}$, respectively.

NMR titration was performed by adding increasing amounts of drugs to the oligonucleotides solution at $\mathrm{R}=[$ ligand $] /[\mathrm{DNA}]$ ratio from 0 to 0.75 (after this value the drug precipitates) for 9 and from 0 to 3.0 for 3 .

Standard homonuclear 2D-NMR experiments were performed to assign the resonances of the complexes, including DQF-COSY, TOCSY and NOESY $[18,19]$. The mixing times were set at $150 \mathrm{~ms}$ and $300 \mathrm{~ms}$ for NOESY and $60 \mathrm{~ms}$ for TOCSY. For samples in $\mathrm{H}_{2} \mathrm{O}$, the excitation sculpting sequences from standard Bruker pulse program libraries were employed.

Typically, 2048 x 1024 data points were acquired using TPPI and transformed to a final $4 \mathrm{~K}$ $\mathrm{x} 4 \mathrm{~K}$ real data matrix after apodisation with a $90^{\circ}$ and $90^{\circ}$-shifted sine-bell squared function in f2and f1-domain, respectively. Baseline correction was achieved by a 5th-degree polynomial function.

The sequential assignments in free and bound oligonucleotides were performed by applying well established procedures for the analysis of double stranded and quadruplex structures.

The program Sparky [20] was used to assign the NOESY cross-peaks. The d(5'-TTA GGG-3' $)_{4}$ and $\mathrm{d}\left(5^{\prime} \text { 'CGAT CG-3') }\right)_{2}$ NMR spectra were previously assigned [21, 22].

\subsection{Molecular Modelling}

The structure of compound 9 was built using a Silicon Graphics 4D35GT workstation running the Insight II and Discover software and was generated using standard bond lengths and angles. Molecular mechanics (MM) and molecular dynamics (MD) was carried out using both CVFF and AMBER forcefield. Molecular docking experiments were performed on an Apple ${ }^{\circledR}$ QuadXeon MacPro workstation with Autodock 4.0. This software uses an empirical scoring function based on the free energy of binding [23, 24]. Among the stochastic search algorithms offered by the Autodock suite, we chose the Lamarckian Genetic Algorithm (LGA) which combines global search (Genetic Algorithm alone) to local search (Solis and Wets algorithm [25]). Genetic algorithms are based on the evolutionary concept in which the solution to an adaptive problem is spread among a genetic pool. In molecular docking, the 'solution' corresponds to the best binding position for the ligand, and it is represented by a 'chromosome' file containing translation, orientation, and torsion 'genes'. Basically, a genetic algorithm creates a randomly placed population of individuals (ligands) and then applies cycles of genetic operators (mutation and crossover) giving rise to new generations until a suitable solution is achieved. The 'solutions' are evaluated through their free energy of binding and (for 9) looking at their agreement with the NOE data. The small molecule compounds (3 and 9) and the quadruplex (obtained from Protein Data Bank 
[http://www.rcsb.org], PDB code 1NP9) were processed using the Autodock Tool Kit (ADT) [26]. Gasteiger-Marsili charges [27] were loaded on the small molecules in ADT and Cornell parameters were used for the phosphorous atoms in the DNA. Solvation parameters were added to the final macromolecule structure using Addsol utility of Autodock. Each docking consisted of an initial population of 50 randomly placed individuals, a maximum number of 200 energy evaluations, a mutation rate of 0.02 , a crossover rate of 0.80 , and an elitism value of 1 . For the local search, the socalled pseudo-Solis and Wets algorithm was applied using a maximum of 250 iterations per local search. The probability of performing local search on an individual in the population was 0.06 and the maximum number of consecutive failures before doubling or halving the local step size was 4 . Fifty independent docking runs were carried out for each ligand. The grid maps representing the system in the actual docking process were calculated with Autogrid. The grids (one for each atom type in the ligand, plus one for electrostatic interactions) were chosen to be sufficiently large to include the entire width of the DNA fragment in which the original inhibitor was posed, together with a portion of minor and major grooves. The simpler intermolecular energy function based on the Weiner force field in Autodock was used to score the docking results. Results differing by less than $1.0 \AA$ in positional root-mean-square deviation ( $\mathrm{rmsd}$ ) were clustered together and represented by the result with the most favourable free energy of binding. Since we could not use rmsd as the only accuracy criterion, we opted for a more subjective yet more representative criterion, which was to classify the resulting binding mode by consistence with the NOE results and visual inspection as intercalation, minor groove binding, or others (major groove binding, interaction with phosphate groups and so on).

\section{Results and discussion}

\subsection{Competitive Dialysis Studies}

To evaluate the selectivity and the affinity of acridine and quindoline derivates for different DNA structures, we performed a competive dialysis experiment using 11 nucleic acid structures [14].

As models for single stranded structures we used T20 and 24bclc. As duplexes we used the selfcomplementary sequences Dickerson-Drew dodecamer (Dickerson) and a 26 mer (ds26). A parallel triplex (TC triplex) and an antiparallel triplex (GA triplex) were also prepared by mixing a hairpin Watson-Crick sequence and the corresponding triplex-forming sequence. Finally, the following Gquadruplex sequences were prepared: the tetramolecular parallel G-quadruplex $\mathrm{TG}_{4} \mathrm{~T}$ [28], the antiparallel thrombin-binding aptamer (TBA) [29], the human telomere sequence (HT24) [30], and 
the promoter sequences of c-myc (cmyc) [15] and bcl-2 (24bcl) [16, 17]. The amount of the bound ligand was directly proportional to the binding constant for each DNA structure [31, 32].

Fig. 2 displays the oligonucleotide affinity for each compound. Fig. 2A showed the results for acridine derivates 1, 2, 5, 6 and 7. Acridine-9-carboxylic 1 interacts only with duplex ds26, the derivate $\mathbf{2}$ with a glycine residue, induced a change in the affinity showing a slight quadruplex preference, in particular for cmyc and 24bcl. On the contrary, the acridine 4-aminoproline oligomers 5, 6 and 7 only interacts with quadruplex structures.

Fig. 2B shows that quindoline-11-carboxylic acid 3, quindoline-11-carboxamide acetic acid 4 monomer $\mathbf{8}$ and trimer $\mathbf{1 0}$ derivatives do not present any selectivity. The affinity and selectivity for the quadruplex structures increases up in the dimer $\mathbf{9}$. The oligonucleotide affinity and selectivity drop down in the mixed dimers 11 and $\mathbf{1 2}$ (Fig. 2C). No selectivity and affinity improvement are observed for the mixed trimers 13-18 (Fig. 2D) compared with the mixed dimers.

\section{2. ${ }^{1} \mathrm{H}$ NMR experiments and molecular modeling on the [9]/[(T2AG3) $\left.{ }_{4}\right]$ complex}

On the basis of dialysis studies compound $\mathbf{9}$ demonstrated the higher affinity and selectivity for the quadruplex structures studied in this work. In order to study in depth this binding, compound 9, which had the higher affinity for quadruplex structures, was titrated into a solution of quadruplex model $(\mathrm{T} 2 \mathrm{AG} 3)_{4}$ contained in the human telomere sequence and the resulting mixtures were analyzed by ${ }^{1} \mathrm{H}-\mathrm{NMR}$. T2AG3 is short model sequence contained in HT24 oligonucleotide. This oligonucleotide has been used previously for NMR characterization of drug binding on telomeric DNA sequences [33]. The short oligonucleotide has a more simple NMR spectrum than HT24 sequence facilitating the study of the interactions of the drug with the DNA sequence.

We performed competitive dialysis experiments with compound 9 including the T2AG3 oligonucleotide (Figure 1S supplementary section). The affinity of compound $\mathbf{9}$ for HT24 is slightly higher than T2AG3 but it is in the range of the high affinity group that includes quadruplex forming oligonucleotide: HT24, cmyc and 24bcl sequences.

Moreover, the buffer conditions used in the competitive dialysis experiments are not appropriate for NMR studies as the salt concentration is too high. NMR experiments were performed in $25 \mathrm{mM}$ $\mathrm{KH}_{2} \mathrm{PO}_{4}, 150 \mathrm{mM} \mathrm{KCl}$ and $1 \mathrm{mM}$ EDTA. Competitive dialysis experiments for quindoline dimer, 9, in both (dialysis and NMR) buffer conditions are included in the supplementary section (Figure 1S). There are small changes but essentially the relative affinities are similar in both buffer conditions. 
The spectra in $\mathrm{H}_{2} \mathrm{O}$ showed three signals, in the region of 11-12 ppm, belonging to Hoogsteenbound guanine imino proton of the G quartets (Fig. 3). The addition of 9 to the quadruplex solution till a ratio $\mathrm{R}=[9] /\left[(\mathrm{T} 2 \mathrm{AG} 3)_{4}\right]=0.75$ basically didn't change the imino proton resonances but causes the appearance of two new down field signals $(+0.3 \mathrm{ppm})$ belonging to a bound species in low chemical exchange. Unfortunately the very low solubility of 9 in water precluded to continue the titration experiment. The non-exchangeable protons of the oligonucleotide showed the appearance of two new signals at 7.80 and $7.26 \mathrm{ppm}$, belonging to the drug, together with a signal at $8.40 \mathrm{ppm}$ attributed to H8A3 in the bound species (Fig. 1S). The spectrum of the 9 without oligonucleotide, because of the high symmetry of the molecule showed only 4 signals on the aromatic protons region (Fig. 2S).

Despite this, NOESY spectra were acquired at $R=[9] /\left[(\mathrm{T} 2 \mathrm{AG} 3)_{4}\right]=0.5$ and 0.75 that revealed few but significant contacts of 9 with T2, A3, G4, G5 and G6 protons indicating a binding to the quadruplex. Some examples are reported in Fig. 4 and Table 1 lists the NOE data and the distances values of the final structure obtained by MD. All the protons of the bound species were attributed and the assignments are reported in Table 2.

A slight stabilization of the complex was proved by a melting experiment that resulted in an increase of the melting temperature $\left(\mathrm{T}_{\mathrm{m}}\right)$ in comparison with the free oligonucleotide (Fig. 5).

The dimer structure of $\mathbf{9}$ was built using the fragment library in Insight II and Discover. Each fragment was optimized by conjugate algorithm and the resulting monomer was also optimized. The dimer was built by joining two monomers and the final structure was optimized once more. Analysis of the resulting geometries revealed that the energetically most favorable conformation was that in which the two aromatic rings adopt a folded structure (Fig. 6) with a angle between aromatic systems around $60^{\circ}$, showing a $\pi$ stack arrangement.

The so-derived structure was then used as a starting point to study its interaction with the quadruplex by using a molecular docking experiment. Because of the interaction between the dimer structure of $\mathbf{9}$ and the quadruplex, all the conformation of the dimer obtained by molecular docking were found to be different than the structure previously optimized and used as a starting point in the calculation. Moreover, none of 9-quadruplex complexes resulting from the calculation has shown the ability of the 9 molecule to intercalate within the quadruplex, probably due to steric hindrance caused by the large size of the dimer.

The analysis of the best solution obtained from molecular docking shows that the dimer molecule binds externally on the two opposite sides of the same strand, stabilized by $\pi$ - $\pi$ stacking interactions between the two aromatic rings of the dimer and the aromatic systems of the nucleotides, clamping one strand of the quadruplex (see fig. 7). By adopting this conformation, the 
ligand is able to interact with T2, A3, G4 and G5 of various strands, a situation which leads to a significant stabilization of the complex in according the melting experiment. The complex is further stabilized by the presence of a strong hydrogen bond between the ligand amide nitrogen and the OP2 oxygen belonging to G4, at a distance of $2.25 \AA$.

The goodness of this conformation was confirmed by NOE data with the distance calculated on the basis of the modeling obtained (Table 1).

We built the model of compound $\mathbf{3}$ and the quadruplex. It was energy-minimized and subjected to a restrained molecular dynamics calculations (MD). The resulting structure was used to obtain a prediction for the complex with the quadruplex structure, using again a molecular docking experiment. Unlike the previous case, the compound $\mathbf{3}$ behaves as a true intercalating agent, fitting completely within the quadruplex, in the pocket between the A3 and G4 units belonging to the four strands (fig. 8). These results agree with the interaction between 5-N-Methyl quindoline derivatives and the same quadruplex structure already described in the literature [33, 34].

The resulting complex is only stabilized by $\pi-\pi$ stacking interactions between the aromatic ring of the ligand and the rings of bases that are located above and below the molecule. The ability of the $\mathbf{3}$ to fit within the quadruplex, and then to behave as a true intercalating agent, indirectly proves what has been stated before, namely that in the case of the dimer $\mathbf{9}$, this possibility is precluded only by steric factors and not by structural and/or electronic characteristics of the molecule.

\section{3. ${ }^{1} \mathrm{H}$ NMR Experiments on the [9]/[d(5'-CGA TCG-3') $\left.{ }_{2}\right]$ complex.}

The increase in the line broadening of the resonances of $\mathrm{NHG}_{2} \mathrm{C}_{5}, \mathrm{NHA} 3 \mathrm{~T} 4$ imino, aromatic and anomeric protons can easily be followed during the titration experiments with $\mathbf{9}$, as shown in Fig. 9. The imino proton $\mathrm{NHC}_{1} \mathrm{G}_{6}$ is difficult to monitor because of the fraying which involve the base pairs terminal ends. A slight shielding at maximum of $0.09 \mathrm{ppm}$ was shown for the aromatic protons. The protons were attributed and the assignments are reported in Table 2. The addition of 9 into double stranded oligonucleotide produces a generalized line broadening. The ${ }^{1} \mathrm{H}$ NOESY spectra of the complex with 9 suggest, even with few number of NOEs interactions, the binding at the level of G2, C5 bases (H8G2/Har, H5and H6C5/Har).

The same titration experiment performed with $\mathbf{3}$ shows no line broadening of imino proton resonances and no chemical shift variations (Fig. 3S Supporting Information) even at high [3] / [d(5'-CGA TCG-3' $\left.)_{2}\right]$ ratio. These observations suggest that compound $\mathbf{3}$ does not interact with short double helix oligonucleotides as it was also confirmed by 2D NOESY experiments which don't show any contact points between drug and oligonucleotide.

\section{Conclusions}


In summary we have used competitive dialysis experiments in order to determine the DNA binding properties of a complete series of 4-aminoproline oligomers carrying up to three units of acridine and quindoline molecule. A high selectivity of quindoline 4-aminoproline oligomers for Gquadruplex and triplex structures was observed. Selectivity for quadruplex was also found for some acridine oligomers but the affinity was lower compared with quindoline oligomers. The affinity of acridine 4-aminoproline oligomers was similar to the affinity described for acridine oligomers built on the 2-aminoethylglycine backbone [14] indicating that both backbones provide similar DNAbinding properties to the resulting oligomers.

A detailed NMR / molecular dynamics study on G-quadruplex telomeric sequence and the 4aminoproline dimer carrying two quindolines shows the reasons of the affinity of the quindoline dimer with the telomeric DNA quadruplex. First the most stable conformation of the quindoline dimer alone adopts a structure in which the two aromatic rings stack with an angle around $60^{\circ}$. This structure fits on the quadruplex clamping one strands and the complex is stabilized by $\pi-\pi$ stacking interactions between the aromatic rings of the ligand and the nucleobases of the telomeric sequence that are located above and below the molecule. The results of this work and specially the model of the complex can be used for the design of new molecules with high affinity to telomeres which may have anticancer properties.

\section{Acknowledgements}

This work was partially supported by grants from Spanish Ministerio de Ciencia e Innovación MICINN (CTQ2005-00315/BQU, CTQ2008-00177, BFU2007-63287, CTQ2009-20541), Generalitat de Catalunya, (2009/SGR/208), CIBER-BBN, Networking Centre on Bioengineering, Biomaterials and Nanomedicine, Institute for Research in Biomedicine, and the Barcelona Science Park. CIBER-BBN is an initiative funded by the VI National R\&D\&i Plan 2008-2011, Iniciativa Ingenio 2010, Consolider Program, CIBER Actions and financed by the Instituto de Salud Carlos III with assistance from the European Regional Development Fund.

\section{References}

[1] R. Palchaudhuri, P.J. Hergerother, DNA as a target for anticancer compounds: methods to determine the mode of binding and the mechanism of action, Curr. Opin. Biotechnol. 18 (2007) 497-503. 
[2] B.A. Neto, A.A. Lapis, Recent developments in the chemistry of deoxyribonucleic acid (DNA) intercalators: principles, design, synthesis, applications and trends, Molecules, 14 (2009) 17251746.

[3] D.P. Arya, B. Willis, Reaching into the major groove of B-DNA: Synthesis and nucleic acid binding of a neomycin-Hoechst 33258 conjugate, J. Am. Chem. Soc. 125 (2003) 12398-12399.

[4] E. Fechter, B. Olenyuk, P.B. Dervan, Design of a sequence specific DNA bis-intercalator, Angew. Chem. Int. Ed. 43 (2004) 3591-3594.

[5] D.J. Patel, A.T. Phan, V. Kuryavyi, Human telomere, oncogenic promoter and 5'-UTR Gquadruplexes: diverse higher order DNA and RNA targets for cancer therapeutics, Nucleic Acids Res. 35 (2007) 7429-7455.

[6] G.N. Parkinson, M.P.H. Lee, S. Neidle, Crystal structure of parallel quadruplexes from human telomeric DNA, Nature, 417 (2002) 876-880.

[7] J.L. Huppert, Hunting G-quadruplexes. Biochimie 90 (2008) 1140-1148.

[8] L.H. Hurley, Secondary DNA structures as molecular targets for cancer therapeutics, Biochem. Soc. Trans. 29 (2001) 692-696.

[9] H. Han, L.H. Hurley, G-quadruplex DNA: a potential target for anti-cancer drug design, Trends in Pharm. Sci. 21 (2000) 136-142.

[10] D. Monchaud, M.P. Teulade-Fichou, A hitchhiker's guide to G-quadruplex ligands. Org. Biomol. Chem. 6 (2008) 627-636.

[11] N.H. Campbell, G.N. Parkinson, A.P. Reszka, S. Neidle, Structural basis of DNA quadruplex recognition by an acridine drug, J. Am. Chem. Soc. 130 (2008) 6722-6724.

[12] A. Aviñó, I. Navarro, J. Farrera-Sinfreu, M. Royo, J. Aymamí, A. Delgado, A. Llebaria, F. Albericio, R. Eritja, Solid-phase synthesis of oligomers carrying several chromophore units linked by phosphodiester backbones, Bioorg. Med. Chem. Lett.18 (2008) 2306-2310.

[13] J. Farrera-Sinfreu, A. Aviñó, I. Navarro, J. Aymamí, N.G. Beteta, S. Varón, R. Pérez-Tomás, W. Castillo-Avila, R. Eritja, F. Albericio, M. Royo, Design, synthesis and antiproliferative properties of oligomers with chromophore units linked by amide backbones, Bioorg. Med. Chem. Lett.18 (2008) 2440-2444.

[14] R. Ferreira, A. Aviñó, R. Pérez-Tomás, R. Gargallo, R. Eritja, Synthesis and G-quadruplexbinding properties of defined acridine oligomers, J. Nucleic Acids (2010) doi:10.4061/2010/489060 article ID 489060, 10 pages.

[15] A. Siddiqui-Jain, C.L. Grand, D.J. Bearss, L.H. Hurley, Direct evidence for a G-quadruplex in a promoter region and its targeting with a small molecule to repress $c$-myc transcription, Proc. Natl. Acad. Sci. USA, 99 (2002) 11593-11598 
[16] J. Dai, J., T.S. Dexheimer, D. Chen, M. Carver, A. Ambrus, R.A Jones, D. Yang, An intermolecular G-quadruplex structure with mixed parallel/antiparallel G-strands formed in the BCL-2 promoter region in solution, J. Am. Chem. Soc., 128 (2006) 1096-1098.

[17] M. Del Toro, P. Puceck, A. Aviñó, J. Jaumot, C. González, R. Eritja, R. Gargallo, Targeting the G-quadruplex-forming region near the P1 promoter in the human BCL-2 gene with the cation porphyrin TMPyP4 and with the complementary C-rich strand. Biochimie 91 (2009) 894-902.

[18] A. Kumar, R.R. Ernst, K. Wüthrich, A two-dimensional nuclear Overhauser enhancement (2D NOE) experiment for the elucidation of complete proton-proton cross-relaxation networks in biological macromolecules, Biochem. Biophys. Res. Comm. 95 (1980) 1-6.

[19] L. Braunschweiler, R.R. Ernst, Coherence transfer by isotropic mixing. Application to proton correlation spectroscopy, J. Magn. Reson. 53 (1983) 521-528.

[20] T.D. Goddard, D.G. Kneller, (2004) SPARKY 3, University of California, San Francisco, USA.

[21] Y. Wang, D.J. Patel, Guanine residues in d(T2AG3) and d(T2G4) form parallel-stranded potassium cation stabilized G-quadruplexes with anti glycosidic torsion angles in solution, Biochemistry 31 (1992) 8112-8119.

[22] S. Mazzini, R. Mondelli, E. Ragg, Structure and dynamics of intercalation complexes of anthracyclines with d(CGATCG)(2) and d(CGTACG)(2). 2D-H-1 and P-31 NMR investigations, J. Chem. Soc., Perkin Trans 2 (1998) 1983-1991.

[23] G.M. Morris, D.S. Goodsell, R.S. Halliday, R. Huey, W.E. Hart, R.K. Belew, A.J. Olson, Automated docking using Lamarckian Genetic Algorithm and an empirical binding free energy function, J. Comput. Chem. 19 (1998) 1639-1662.

[24] R. Huey, G.M. Morris, A.J. Olson, D.S. Goodsell, A semiempirical free energy force field with charge-based desolvation, J. Comput. Chem. 28 (2007) 1145-1152.

[25] F.J. Solis, J.-B.Wets, Minimization by random search techniques, Math. Oper. Res. 6 (1981) $19-30$.

[26] M.F. Sanner, Python: a programming language for software integration and development, J. Mol. Graphics Modell. 17 (1999) 57-61

[27] J. Gasteiger, M. Marsili, Iterative partial equalization of orbital electronegativity - a rapid access to atomic charges, Tetrahedron 36 (1980) 3219-3228.

[28] J. Gros, F. Rosu, S. Amrane, A. De Cian, V. Gabelica, L. Lacroix, J.L. Mergny, Guanines are a quartet's best friends: impact of base substitutions on the kinetics and stability of tetramolecular quadruplexes, Nucleic Acids Res., 35 (2007) 3064-3075. 
[29] L.C. Bock, L.C. Griffin, J. A. Latham, E.H. Vermaas, J.J. Toole, Selection of single-stranded DNA molecules that bind and inhibit human thrombin, Nature 355 (1992) 564-566.

[30] Y. Wang, D.J. Patel, Solution structure of the human telomeric repeat $d\left[\mathrm{AG}_{3}\left(\mathrm{~T}_{2} \mathrm{AG}_{3}\right)_{3}\right]$ Gtetraplex, Structure, 1 (1993) 263-282.

[31] J. Ren, J.B. Chaires, Sequence and structural selectivity of nucleic acid binding ligands, Biochemistry, 38 (1999) 16067-16075.

[32] P. Ragazzon, J.B. Chaires, Use of competition dialysis in the discovery of G-quadruplex selective ligands, Methods, 43 (2007) 313-323.

[33] Y.J. Lu, T.M. Ou, J.H. Tan, J.Q. Hou, W.Y. Shao, D. Peng, N. Sun, X.D. Wang, W.B. Wu, X.Z. Bu, Z.S. Huang, D.L. Ma, K.Y. Wong, L.Q. Gu, 5-N-Methylated quindoline derivatives as telomeric G-quadruplex stabilizing ligands: Effects of 5-N positive charge on quadruplex binding affinity and cell proliferation, J. Med. Chem. 51 (2008) 6381-6392.

[34] O.Y. Fedoroff, M. Salazar, H. Han, V.V. Chemeris, S.M. Kerwin, L.H. Hurley, NMR-based model of a telomerase-inhibiting compound bound to G-quadruplex DNA. Biochemistry 37 (1998) 12367-12374. 
Table 1. Intermolecular NOE interactions and inter-proton distances $(\AA)$ for the complex of 9 with $(\mathrm{T} 2 \mathrm{AG} 3)_{4}^{\mathrm{a}}$

\begin{tabular}{|c|c|c|}
\hline 9 & d(TTAGGG) $)_{4}$ & $d^{b}$ \\
\hline \multirow[t]{8}{*}{$\mathrm{H}(7.80 \mathrm{ppm})$} & $1^{\prime}-\mathrm{H} \mathrm{A}_{3}$ & $4.60 \mathrm{I}$ \\
\hline & 8- $\mathrm{H} \quad \mathrm{G}_{4}$ & $5.06 \mathrm{II}$ \\
\hline & $2^{\prime}-\mathrm{H} \quad \mathrm{G}_{4}$ & $5.20 \mathrm{II}$ \\
\hline & $2 “-H \quad G_{5}$ & $4.38 \mathrm{II}$ \\
\hline & $3^{\prime}-\mathrm{H} \quad \mathrm{G}_{5}$ & $5.61 \mathrm{II}$ \\
\hline & $4^{\prime}-\mathrm{H} \quad \mathrm{G}_{5}$ & $3.58 \mathrm{I}$ \\
\hline & $4^{\prime}-\mathrm{H} \quad \mathrm{G}_{6}$ & $4.95 \mathrm{II}$ \\
\hline & $\mathrm{CH}_{3} \mathrm{~T}_{2}$ & $2.86 \mathrm{I}$ \\
\hline \multirow[t]{3}{*}{$\mathrm{H}(7.26 \mathrm{ppm})$} & $1^{\prime}-\mathrm{H} \quad \mathrm{A}_{3}$ & 3.92 II \\
\hline & $1^{\prime}-\mathrm{H} \quad \mathrm{A}_{3}$ & $5.18 \mathrm{I}$ \\
\hline & $\mathrm{CH} 3 \mathrm{~T}_{2}$ & $3.75 \mathrm{I}$ \\
\hline
\end{tabular}

Distance violations $(>0.3 \AA)$

${ }^{a}$ Acquired at $25^{\circ} \mathrm{C}, \mathrm{H}_{2} \mathrm{O}-\mathrm{D}_{2} \mathrm{O}(90: 10 \mathrm{v} / \mathrm{v}), \mathrm{pH}$ 6.7, $25 \mathrm{mM} \mathrm{KH}_{2} \mathrm{PO}_{4}, 150 \mathrm{mM} \mathrm{KCl}$ and $1 \mathrm{mM}$ EDTA. 2'-H and 2"-H stand for low field and up field proton, respectively.

b Obtained from the best structures of the complex resulting from the molecular docking studies. The distances are referred to the $T_{1}-G_{6}$ also in different strands (I and II). 
Table 2. ${ }^{1} \mathrm{H}$ chemical shift values for the complexes d(5'-TTA GGG-3' $)_{4}{ }^{a}$ and d( $5^{\prime}$-CGA TCG$\left.3^{\prime}\right)_{2}^{\mathrm{b}}$ with 9.

\begin{tabular}{|c|c|c|c|}
\hline Protons & $(\text { TTAGGG })_{4} / 9$ & \begin{tabular}{|l|} 
Protons \\
\end{tabular} & $\left(\right.$ CGATCG $_{2} / 9$ \\
\hline NH G4 & 11.60 & $\mathrm{NHC}_{1} \mathrm{G}_{6}$ & n.d. \\
\hline NH G5 & 11.20 & $\mathrm{NHG}_{2} \mathrm{C}_{5}$ & 12.92 \\
\hline NH G6 & 10.51 & $\mathrm{NHA}_{3} \mathrm{~T}_{4}$ & 13.66 \\
\hline $6 \mathrm{H} \mathrm{T1}$ & 7.40 & $\mathrm{NH}_{2} \mathrm{C}_{1}$ & $8.28,7.07$ \\
\hline $6 \mathrm{H} \mathrm{T} 2$ & 7.29 & $\mathrm{NH}_{2} \mathrm{C}_{5}$ & $8.63,7.07$ \\
\hline $8 \mathrm{H} \mathrm{A} 3$ & 8.42 & $6 \mathrm{H} \mathrm{C}_{1}$ & 7.67 \\
\hline $2 \mathrm{H} \mathrm{A}_{3}$ & 8.05 & $8 \mathrm{H} \mathrm{G}_{2}$ & 8.03 \\
\hline $8 \mathrm{H} \mathrm{G} 4$ & 7.76 & $8 \mathrm{H} \mathrm{A}_{3}$ & 8.34 \\
\hline $8 \mathrm{H} \mathrm{G5}$ & 7.48 & $2 \mathrm{H} \mathrm{A}_{3}$ & 7.93 \\
\hline 8H G6 & 7.34 & $8 \mathrm{H} \mathrm{G}_{6}$ & 8.00 \\
\hline $\mathrm{CH}_{3} \mathrm{~T}_{1}$ & 1.67 & $6 \mathrm{H} \mathrm{T}_{4}$ & 7.25 \\
\hline $\mathrm{CH}_{3} \mathrm{~T}_{2}$ & 1.75 & $6 \mathrm{H} \mathrm{C}_{5}$ & 7.53 \\
\hline 1'H T1 & 5.99 & $5 \mathrm{H} \mathrm{C}_{1}$ & 6.00 \\
\hline 1'H T2 & 6.22 & $5 \mathrm{H} \mathrm{C}_{5}$ & 5.70 \\
\hline 1'H A3 & 6.24 & $\mathrm{CH}_{3} \mathrm{~T}_{4}$ & 1.45 \\
\hline 1'H G4 & 6.00 & $1^{\prime} \mathrm{H} \mathrm{C}_{1}$ & 5.76 \\
\hline 1'H G5 & 6.00 & $1^{\prime} \mathrm{H} \mathrm{G}_{2}$ & 5.91 \\
\hline 1'H G6 & 6.09 & $1^{\prime} \mathrm{H} \mathrm{A}_{3}$ & 6.36 \\
\hline $2^{\prime}{ }^{\prime}{ }^{\prime} \mathrm{H} \mathrm{T}_{1}$ & $2.33,2.08$ & $1{ }^{\prime} \mathrm{H} \mathrm{T}_{4}$ & 6.00 \\
\hline $2^{\prime}{ }^{\prime}{ }^{\prime} \mathrm{H} \mathrm{T}_{2}$ & $2.33,2.03$ & $1^{\prime} \mathrm{H} \mathrm{C}_{5}$ & 5.77 \\
\hline $2^{\prime}{ }^{\prime}{ }^{\prime} \mathrm{H} \mathrm{A}_{3}$ & $2.85,2.85$ & $1^{\prime} \mathrm{H} \mathrm{G}_{6}$ & 6.20 \\
\hline $2{ }^{\prime}, \mathrm{H} \mathrm{G}_{4}$ & $2.80,2.56$ & $22^{\prime}{ }^{\prime} \mathrm{H} \mathrm{C}_{1}$ & $2.45,1.93$ \\
\hline $2{ }^{\prime}{ }^{\prime \prime} \mathrm{H} \mathrm{G}_{5}$ & $2.86,2.69$ & $2 ’ 2{ }^{\prime}{ }^{\prime} \mathrm{G}_{2}$ & $2.89,2.78$ \\
\hline $2{ }^{\prime}{ }^{\prime \prime} \mathrm{H} \mathrm{G}_{6}$ & $2.83,2.60$ & $2^{\prime} 2^{\prime \prime} \mathrm{H} \mathrm{A}_{3}$ & $3.02,2.75$ \\
\hline $3^{\prime} \mathrm{H} \mathrm{T}_{1}$ & 4.65 & $2{ }^{\prime}{ }^{\prime} \mathrm{H} \mathrm{T}_{4}$ & $2.48,2.07$ \\
\hline $3^{\prime} \mathrm{H} \mathrm{T}_{2}$ & 4.72 & $22^{\prime}, \mathrm{H} \mathrm{C}_{5}$ & $2.40,2.08$ \\
\hline $3^{\prime} \mathrm{H} \mathrm{A}_{3}$ & 5.08 & $2 ’ 2{ }^{\prime} \mathrm{H} \mathrm{G}_{6}$ & $2.68,2.41$ \\
\hline $3^{\prime} \mathrm{H} \mathrm{G}_{4}$ & 4.98 & $3^{\prime} \mathrm{H} \mathrm{C}_{1}$ & 4.63 \\
\hline $3^{\prime} \mathrm{H} \mathrm{G}_{5}$ & 5.02 & $3^{\prime} \mathrm{H} \mathrm{G}_{2}$ & 5.04 \\
\hline $3^{\prime} \mathrm{H} \mathrm{G}_{6}$ & 4.85 & $3^{\prime} \mathrm{H} \mathrm{A}_{3}$ & 5.07 \\
\hline $4^{\prime} \mathrm{H} \mathrm{T}_{1}$ & 3.98 & $3^{\prime} \mathrm{H} \mathrm{T}_{4}$ & 5.08 \\
\hline $4^{\prime} \mathrm{H} \mathrm{T}_{2}$ & 4.05 & $3^{\prime} \mathrm{H} \mathrm{C}_{5}$ & 4.86 \\
\hline $4^{\prime} \mathrm{H} \mathrm{A}_{3}$ & 4.44 & $3^{\prime} \mathrm{H} \mathrm{G}_{6}$ & 4.72 \\
\hline $4^{\prime} \mathrm{H} \mathrm{G}_{4}$ & 4.49 & $4^{\prime} \mathrm{H} \mathrm{C}_{1}$ & 4.17 \\
\hline $4^{\prime} \mathrm{H} \mathrm{G}_{5}$ & 4.30 & 4' $\mathrm{H} \mathrm{G}_{2}$ & n.d. \\
\hline $4^{\prime} \mathrm{H} \mathrm{G}_{6}$ & 4.47 & $4^{\prime} \mathrm{H} \mathrm{A}_{3}$ & 4.53 \\
\hline & & $5^{\prime} 5^{\prime \prime} \mathrm{H} \mathrm{C} 1$ & 4.02 \\
\hline & & $5^{\prime} 5^{\prime \prime} \mathrm{H} \mathrm{G}_{2}$ & $4.02,4.02$ \\
\hline & & $5^{\prime} 5^{\prime \prime} \mathrm{H} \mathrm{C}_{5}$ & $4.20,4.17$ \\
\hline & & $5^{\prime} 5^{\prime \prime} \mathrm{H} \mathrm{G}_{6}$ & $4.12,4.06$ \\
\hline & & $5^{\prime} 5^{\prime \prime} \mathrm{H} \mathrm{A}_{3}$ & $4.28,4.14$ \\
\hline & & $5,5^{\prime \prime} \mathrm{H} \mathrm{T}_{4}$ & $4.34,4.22$ \\
\hline
\end{tabular}

${ }^{\mathrm{a}}$ Measured at $25^{\circ} \mathrm{C}$ in ppm $(\delta)$ and referenced from external DSS, $\mathrm{H}_{2} \mathrm{O}-\mathrm{D}_{2} \mathrm{O}$ $(90: 10 \mathrm{v} / \mathrm{v}), \mathrm{pH} 6.7,25 \mathrm{mM} \mathrm{KH}_{2} \mathrm{PO}_{4}, 150 \mathrm{mM} \mathrm{KCl}$ and $1 \mathrm{mM}$ EDTA. ${ }^{\mathrm{b}}$ Measured at $15^{\circ} \mathrm{C}$ in ppm $(\delta)$ and referenced from external DSS. Solvent $\mathrm{H}_{2} \mathrm{O}-\mathrm{D}_{2} \mathrm{O}(90: 10 \mathrm{v} / \mathrm{v})$; $\mathrm{pH} 6.7, \mathrm{R}=[\mathbf{9}] /[\mathrm{DNA}]=1$. 


\section{FIGURES}

Fig. 1: Structure of the acridine and quindoline derivates.<smiles>[R]c1c2ccccc2nc2ccccc12</smiles>

1: $\mathrm{R}=\mathrm{COOH}$

2: $\mathrm{R}=\mathrm{CONHCH}_{2} \mathrm{COOH}$

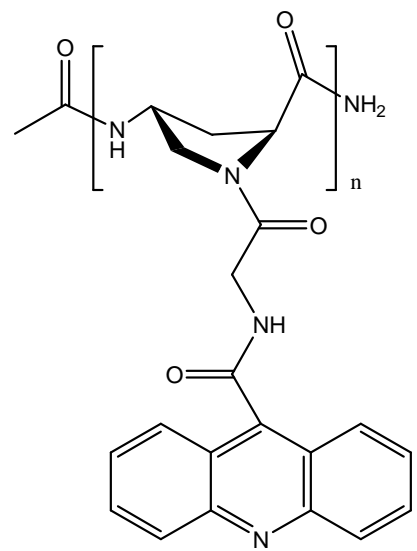

5, 6 and 7: $n=1,2$ and 3

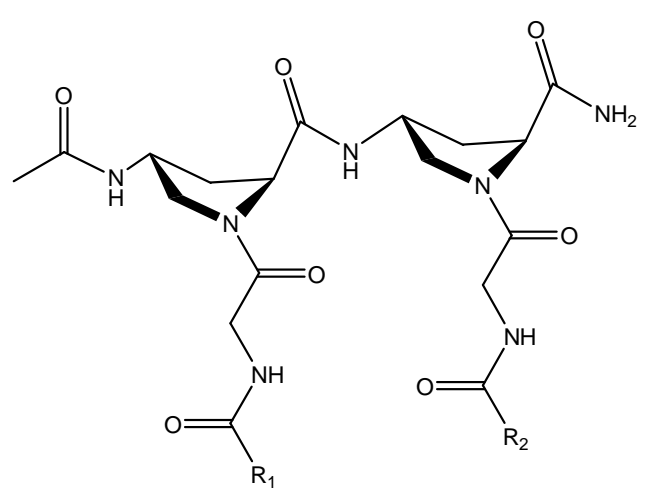

11: $\mathrm{R}_{1}=$ Acridine, $\mathrm{R}_{2}=$ Quindoline

12: $\mathrm{R}_{1}=$ Quindoline, $\mathrm{R}_{2}=$ Acridine<smiles>Brc1c2ccccc2nc2c1[nH]c1ccccc12</smiles>

3: $\mathrm{R}=\mathrm{COOH}$

4: $\mathrm{R}=\mathrm{CONHCH}_{2} \mathrm{COOH}$<smiles></smiles>

8, 9 and 10: $n=1,2$ and 3

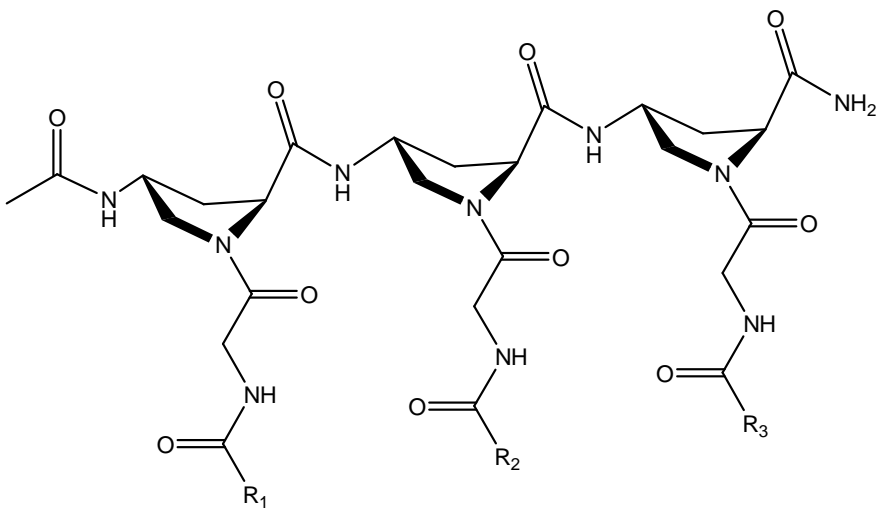

13: $R_{1}=$ Acridine, $R_{2}=$ Acridine, $R_{3}=$ Quindoline

14: $R_{1}=$ Acridine, $R_{2}=$ Quindoline, $R_{3}=$ Acridine

15: $R_{1}=$ Quindoline, $R_{2}=$ Acridine, $R_{3}=$ Acridine

16: $R_{1}=$ Acridine, $R_{2}=$ Quindoline, $R_{3}=$ Quindoline

17: $\mathrm{R}_{1}=$ Quindoline, $\mathrm{R}_{2}=$ Quindoline, $\mathrm{R}_{3}=$ Acridine

18: $R_{1}=$ Quindoline, $R_{2}=$ Acridina, $R_{3}=$ Quindoline 
Fig. 2. Results obtained by the competitive dialysis assay. The amount of ligand (Figure 1) bound to each DNA structure is shown as a bar graph. The nucleic acid names are given on the left, and structures are described in material and method section. The values are normalized for each compound. A) acridine derivatives: monomers 1, 2, 5, acridine dimer 6 and acridine trimer 7. B) quindoline derivatives: monomers $3,4,8$, quindoline dimer 9 and quindoline trimer 10. C) dimers carrying acridine and quindoline 11, 12. D) trimers carrying acridine and quindoline 13-18.
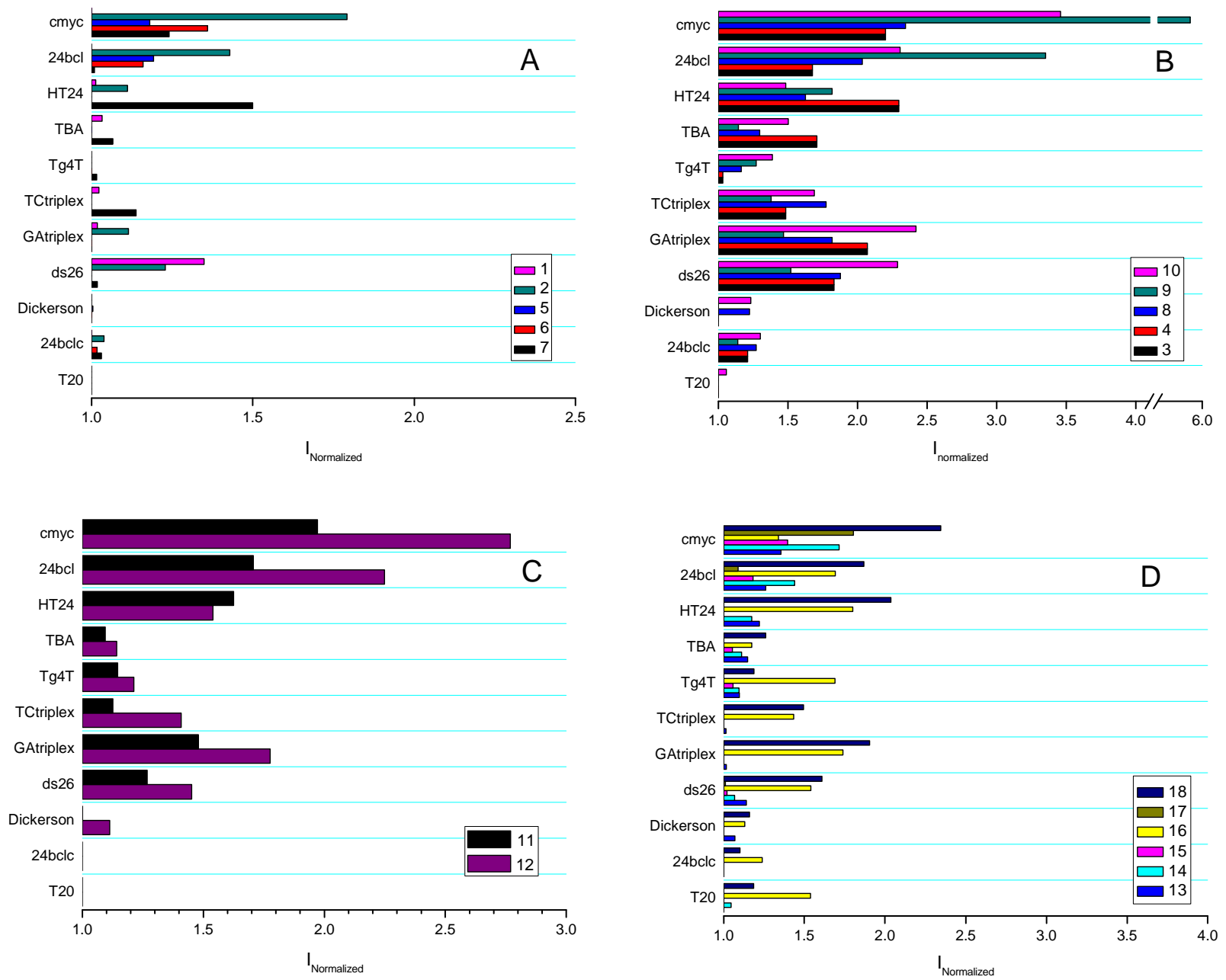
Fig. 3. Low field region of ${ }^{1} \mathrm{H}$ NMR spectra of (T2AG3) 4 / 9 complex in $\mathrm{H}_{2} \mathrm{O}, 25 \mathrm{mM} \mathrm{K \textrm {K } _ { 2 }} \mathrm{PO}_{4}, 150$ $\mathrm{mM} \mathrm{KCl}, 1 \mathrm{mM}$ EDTA $(\mathrm{pH} 6.7), 25^{\circ} \mathrm{C}$ at different $\mathrm{R}=$ [9] / [(T2AG3) 4 . The resonances belonging to the bound species are indicated by an asterisk.

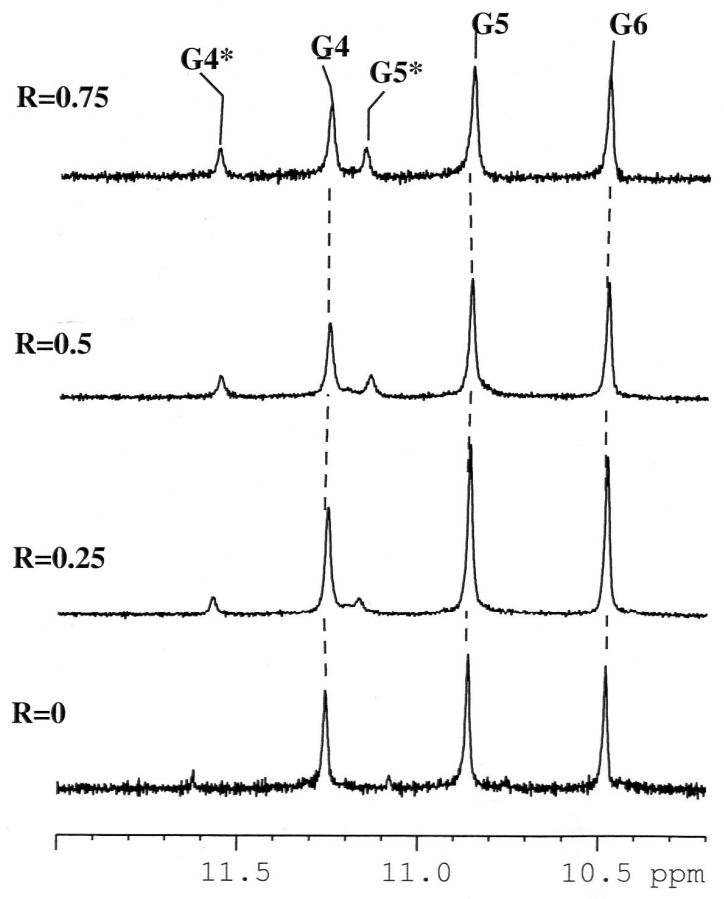


Fig. 4: 2D NOESY spectrum of $(\mathrm{T} 2 \mathrm{AG} 3)_{4} / 9$ complex at $\mathrm{R}=[\mathbf{9}] /\left[(\mathrm{T} 2 \mathrm{AG} 3)_{4}\right]=0.75,25 \mathrm{mM}$ $\mathrm{KH}_{2} \mathrm{PO}_{4}, 150 \mathrm{mM} \mathrm{KCl}$ and $1 \mathrm{mM}$ EDTA $\left(\mathrm{pH}\right.$ 6.7) at $25^{\circ} \mathrm{C}$. Intra and inter residues interactions were shown. Extra aromatic protons of 9 and (T2AG3) $)_{4}$ contacts were observed with: (a) $\mathrm{CH}_{3} \mathrm{~T} 2$, (b) $\mathrm{H} 2{ }^{\prime} \mathrm{G} 5$, (c) $\mathrm{H} 2$ ' G4 (d) $\mathrm{CH}_{3} \mathrm{~T} 2$.

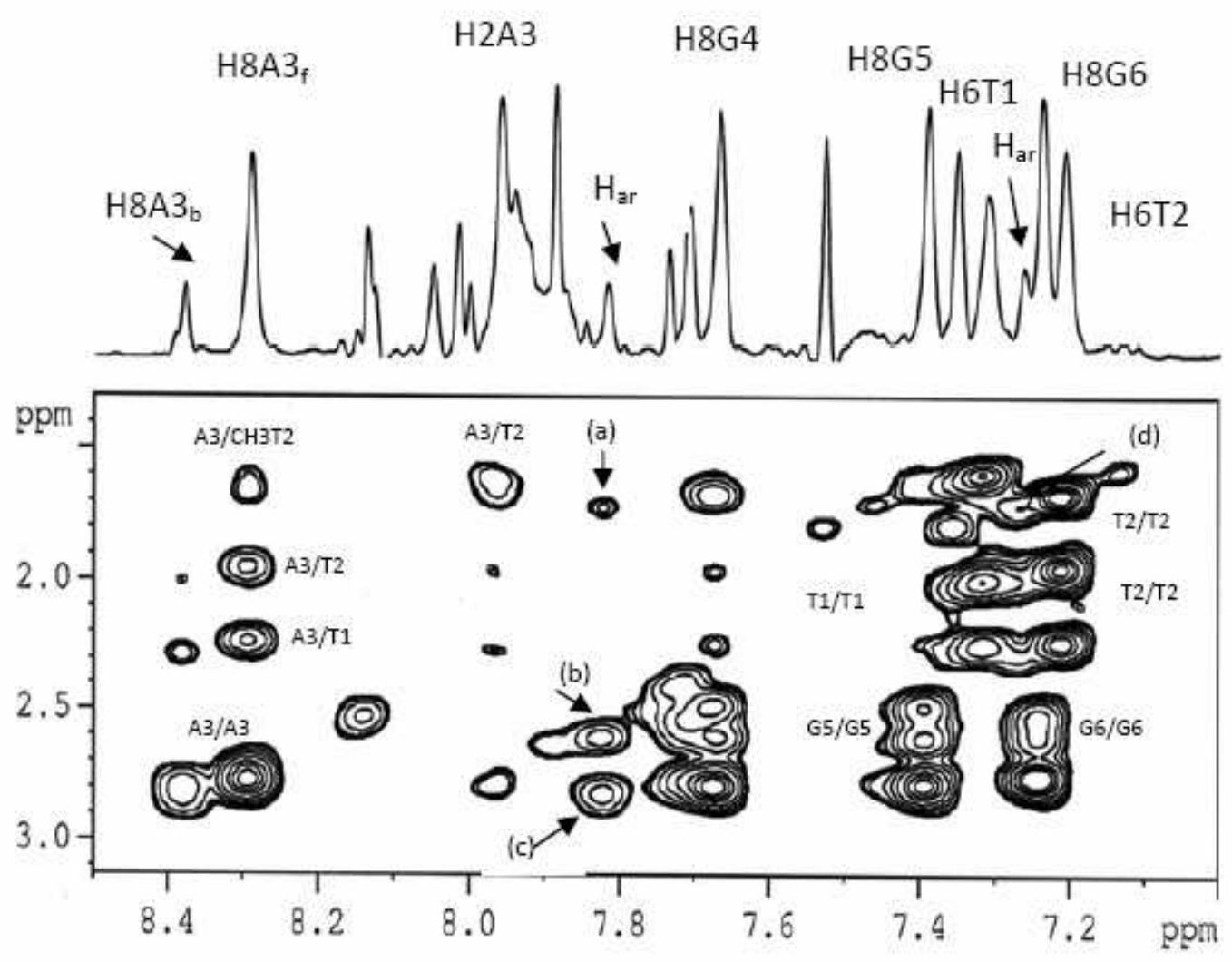


Fig. 5: Thermal denaturation of the parallel (T2AG3) $)_{4}$ quadruplex structure $\left(25 \mathrm{mM} \mathrm{KH}_{2} \mathrm{PO}_{4}, 150\right.$ $\mathrm{mM} \mathrm{KCl}$ and $1 \mathrm{mM}$ EDTA, $\mathrm{pH}$ 6.7). On the left is shown the spectrum of DNA alone and on the right the spectrum of the complex with 9.

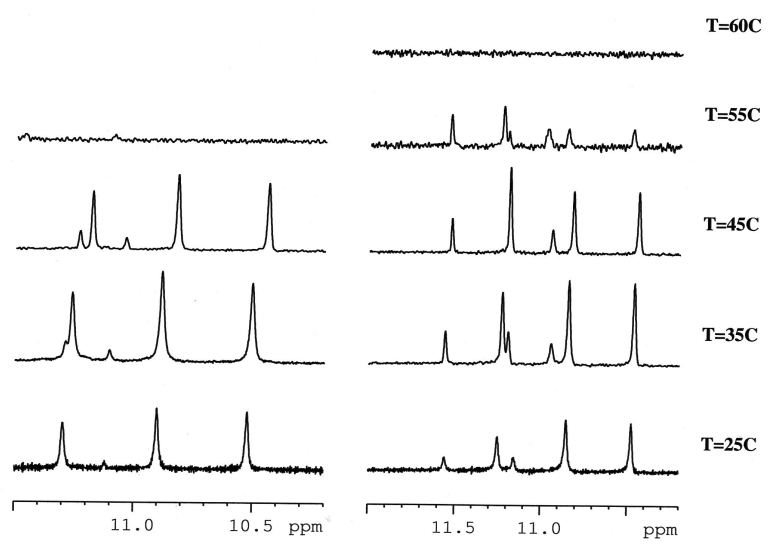


Fig. 6: Energy minimized structure of 9.

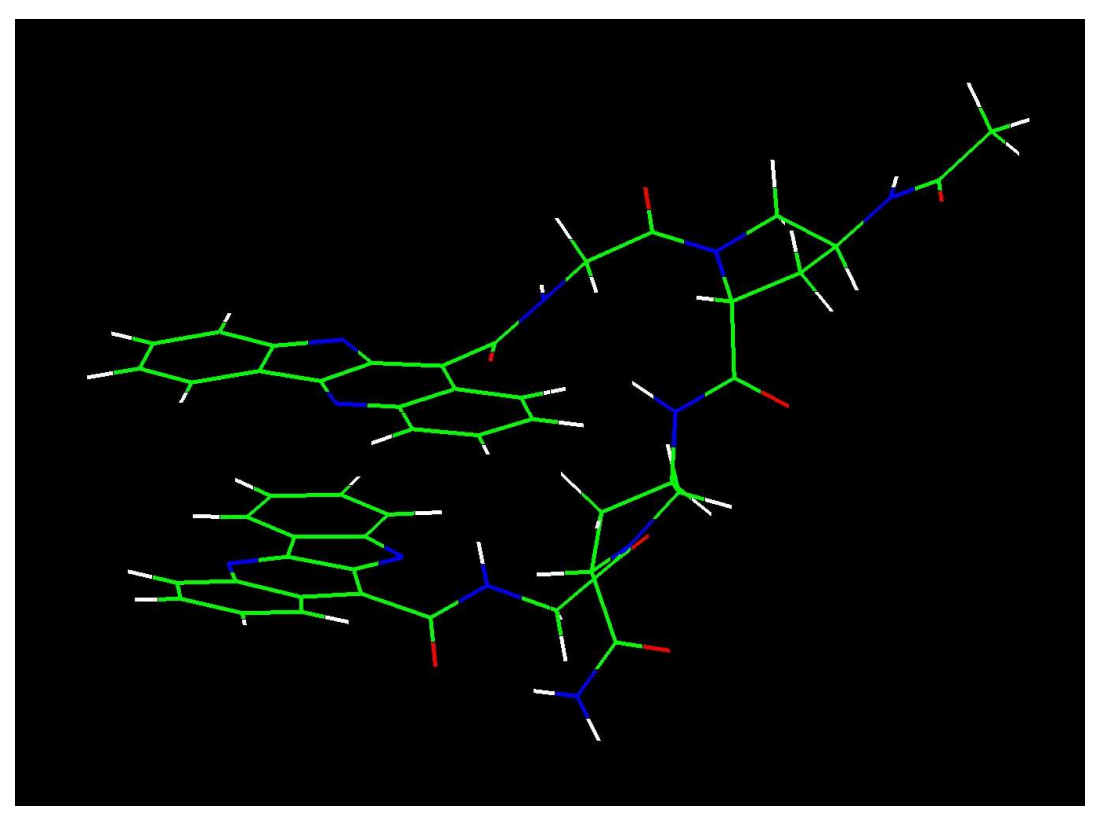


Fig. 7: Lateral (left) and upper (right) views of the 9-quadruplex best-solution obtained from molecular docking calculations. Both molecules are represented by their solvent accessible surfaces (SAS), green for the 9 molecule and yellow for the quadruplex (PDB code:1NP9).

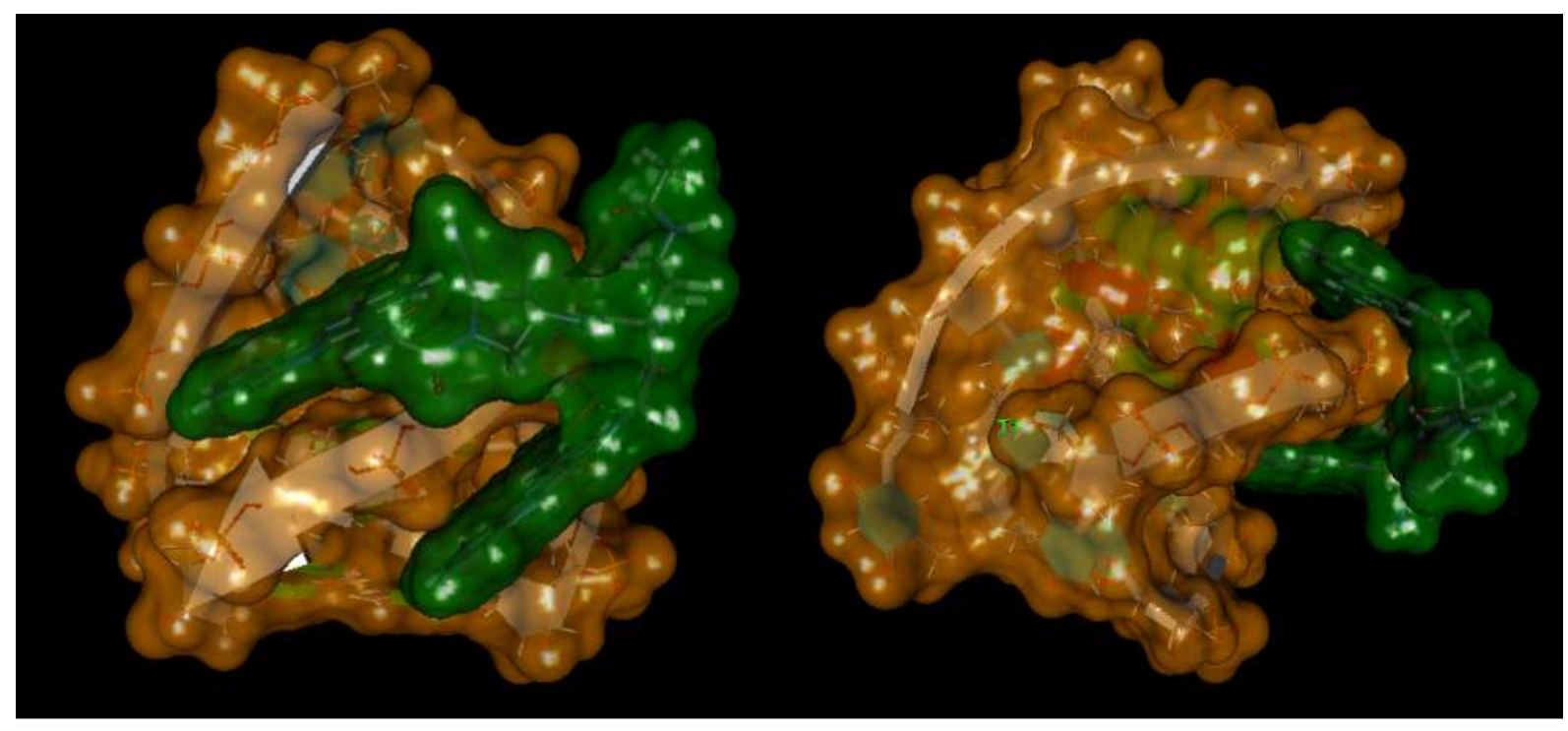


Fig. 8: Schematic drawing of the lowest energy intercalation complex 3-quadruplex obtained from molecular docking calculation. The ligand is represented in stick, while quadruplex is in rings style, surrounded by the solvent accessible surface.

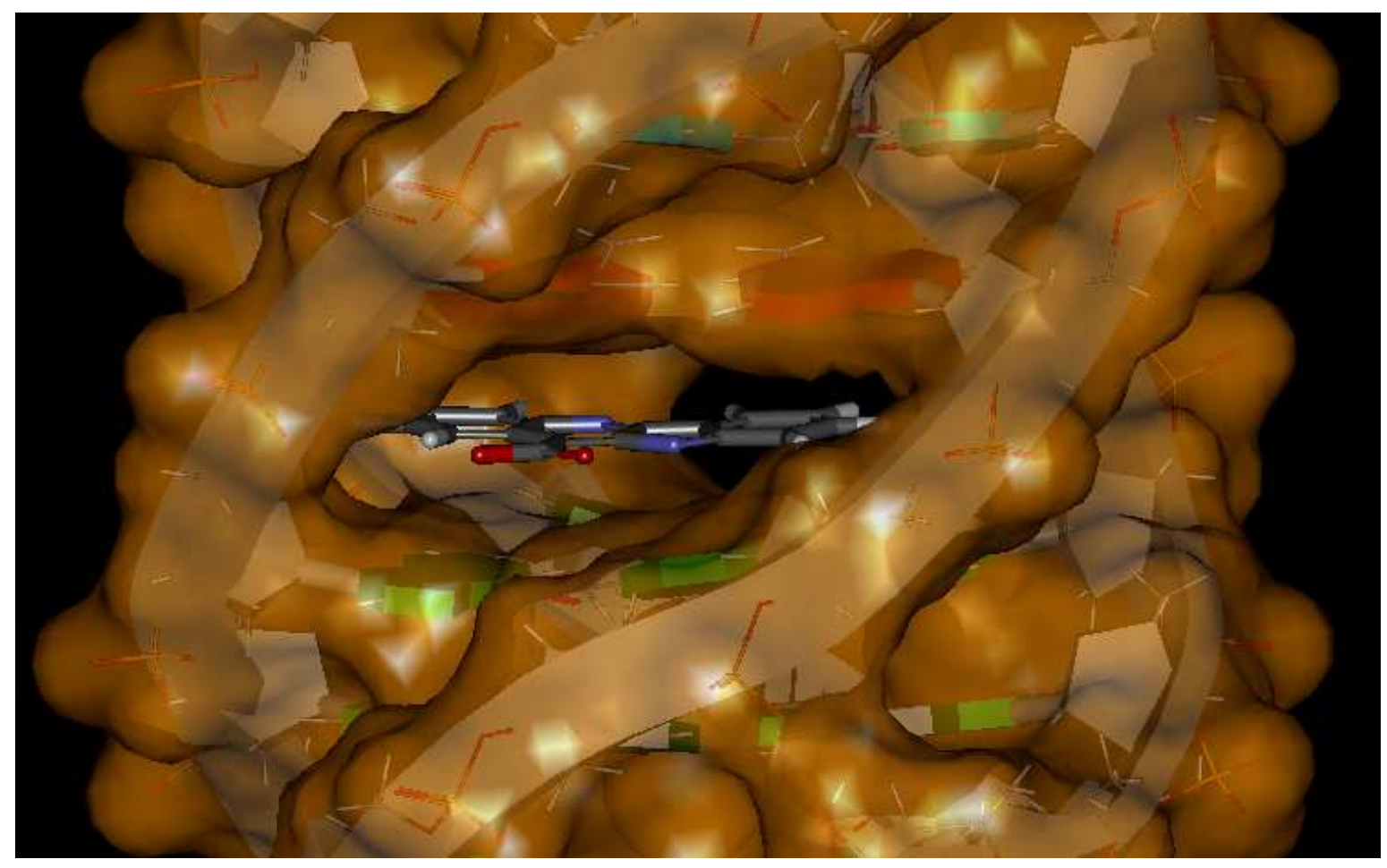


Fig. 9: Imino and aromatic protons region of ${ }^{1} \mathrm{H}$ NMR spectra of d(5'-CGA TCG-3' $)_{2} / 9$ complex in $\mathrm{H}_{2} \mathrm{O}, 10 \mathrm{mM} \mathrm{KH} \mathrm{PO}_{4}, 70 \mathrm{mM} \mathrm{KCl}$ and $0.2 \mathrm{mM}$ EDTA $(\mathrm{pH} 7.0), 15^{\circ} \mathrm{C}$ at different $\mathrm{R}=[9] /\left[\mathrm{d}\left(5^{\prime}-\right.\right.$ CGA TCG-3') ${ }_{2}$ ].

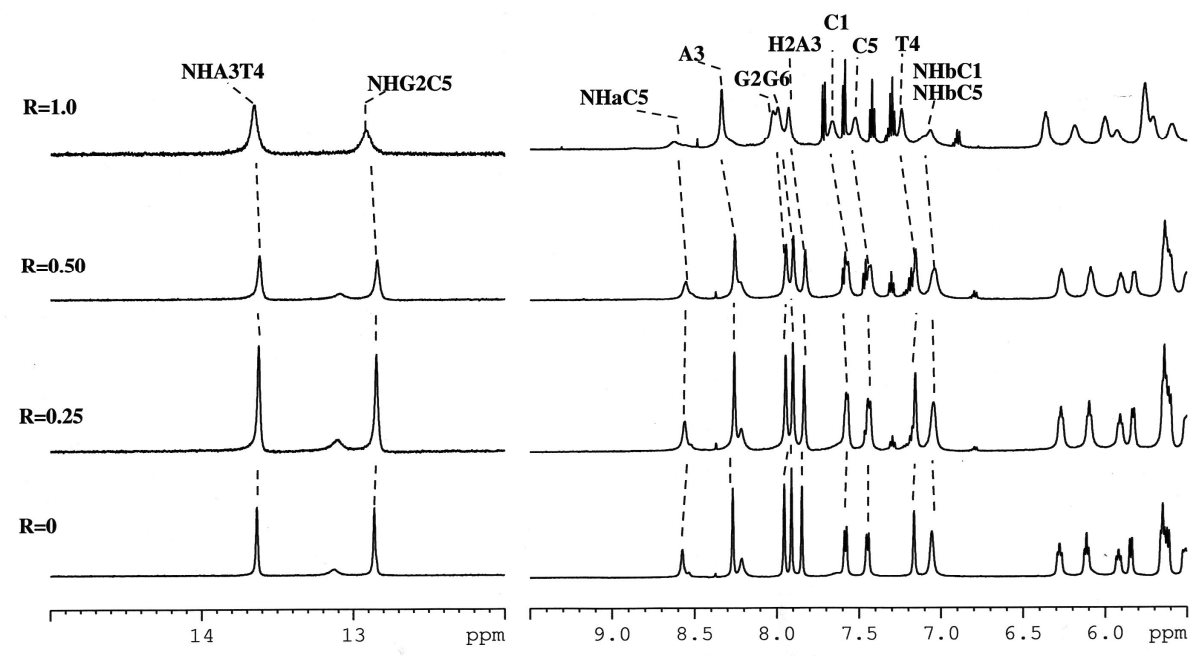




\section{Supporting Information}

Acridine and quindoline oligomers linked through a 4-aminoproline backbone prefer Gquadruplex structures

Rubén Ferreira, Roberto Artali, Josep Farrera-Sinfreu, Fernando Albericio, Miriam Royo, Ramon Eritja, Stefania Mazzini

\section{INDEX}

Figure 1S. Competitive dialysis assay for compound 9.

Figure 2S. Aromatic protons region of ${ }^{1} \mathrm{H}$ NMR spectra of $(\mathrm{T} 2 \mathrm{AG} 3)_{4} / 9$ complex 3

Figure 3S. Aromatic protons region of ${ }^{1} \mathrm{H}$ NMR spectrum of 9 in $\mathrm{D}_{2} \mathrm{O}$. 3

Figure 4S. Imino and aromatic protons region of ${ }^{1} \mathrm{H}$ NMR spectra of (CGATCG) $)_{2} / 3$ complex. 4 
A

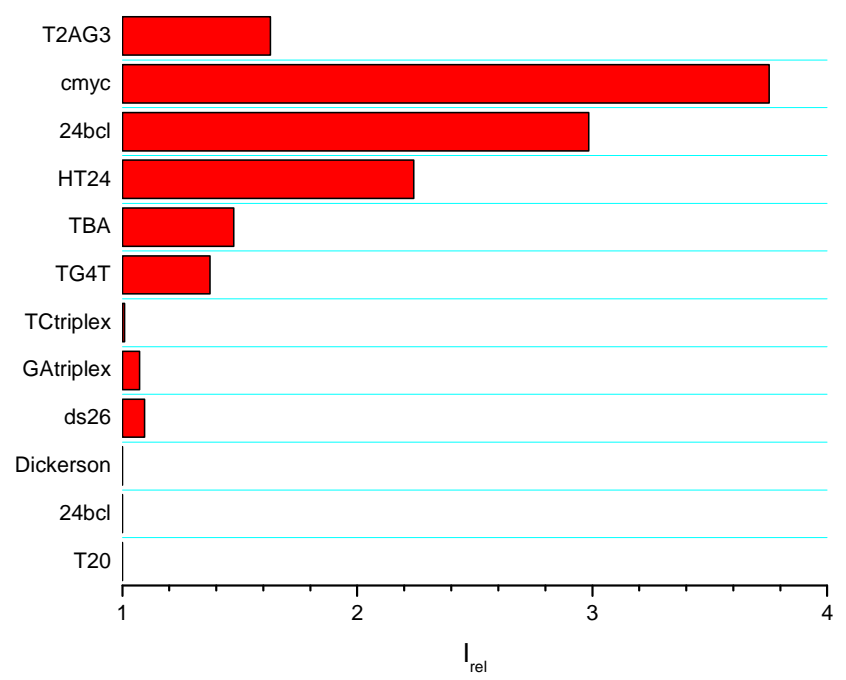

B

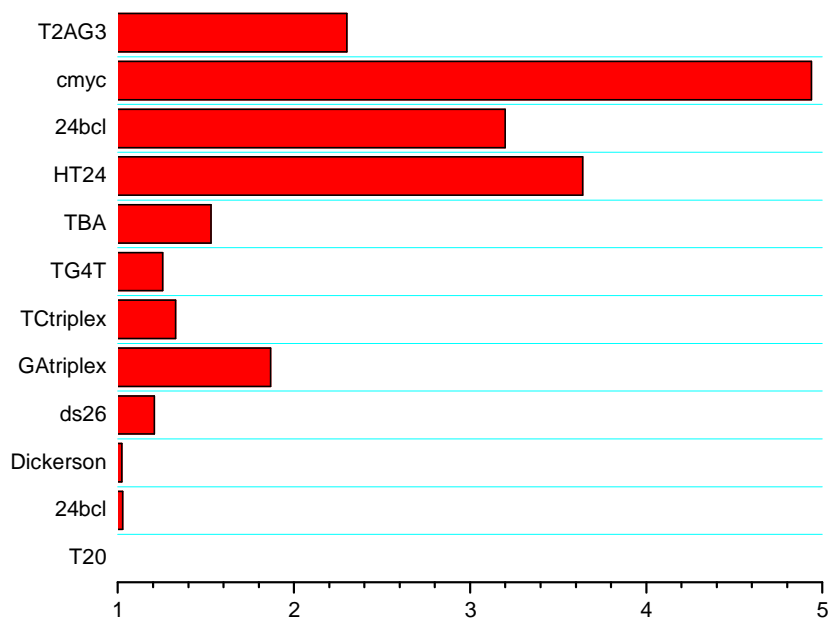

Figure 1S. Competitive dialysis assay for compound 9. A) $185 \mathrm{mM} \mathrm{NaCl}, 185 \mathrm{mM} \mathrm{KCl}, 2 \mathrm{mM}$ $\mathrm{NaH}_{2} \mathrm{PO}_{4}, 1 \mathrm{mM}$ EDTA and $6 \mathrm{mM} \mathrm{Na} \mathrm{HPO}_{4}$ (same conditions than competitive dialysis experiments shown in Figure2). B) $25 \mathrm{mM} \mathrm{KH}_{2} \mathrm{PO}_{4}, 150 \mathrm{mM} \mathrm{KCl}$ and $1 \mathrm{mM}$ EDTA (same conditions than NMR studies). The oligonucleotide sequence $\mathrm{T}_{2} \mathrm{AG}_{3}$ used in NMR studies is included in addition to the oligonucleotides shown in Figure 2. 
(d)

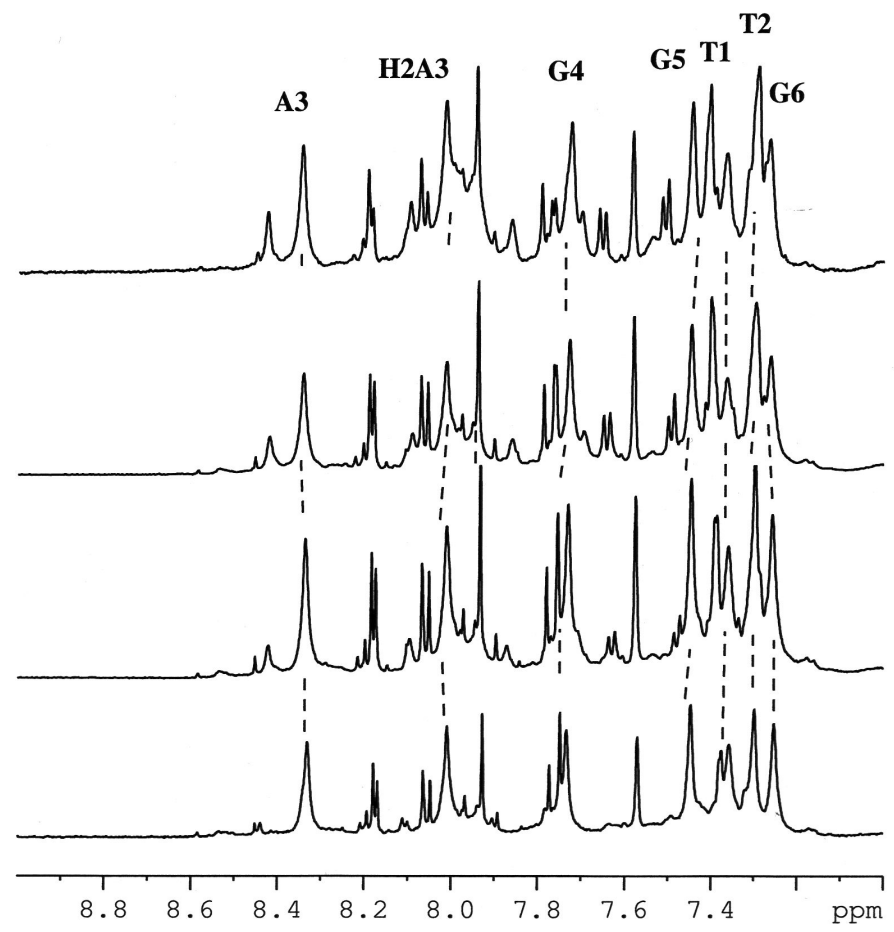

Figure 2S. Aromatic protons region of ${ }^{1} \mathrm{H}$ NMR spectra of (T2AG3) $/ 9$ complex in $\mathrm{H}_{2} \mathrm{O}, 25 \mathrm{mM}$ $\mathrm{KH}_{2} \mathrm{PO}_{4}, 150 \mathrm{mM} \mathrm{KCl}$ and $1 \mathrm{mM}$ EDTA, pH 6.7, 25 ${ }^{\circ} \mathrm{C}$ at different $\mathrm{R}=[9] /\left[(\mathrm{T} 2 \mathrm{AG} 3)_{4}\right]$ : (a) 0, (b) 0.25 , (c) 0.5 , (d) 0.75 .

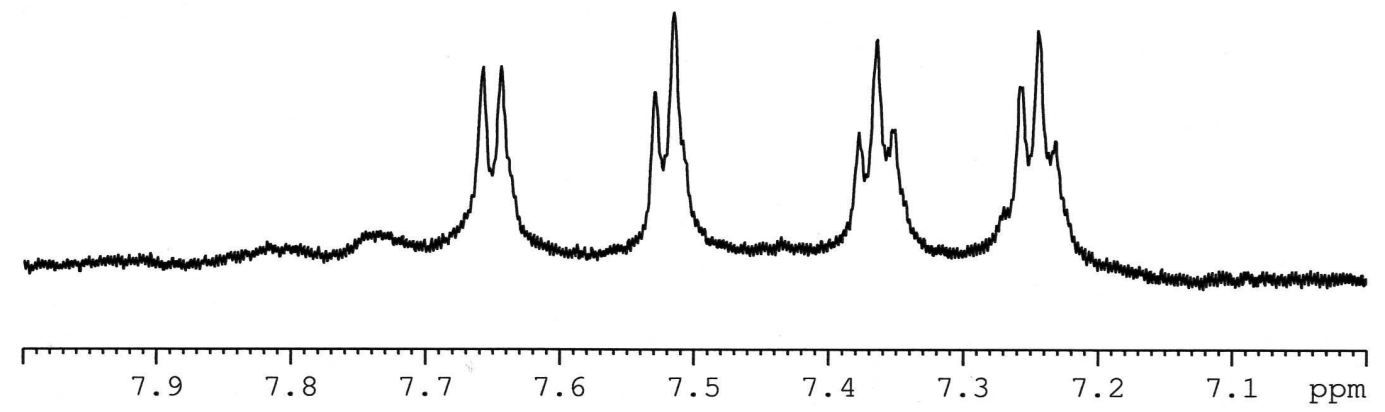

Figure 3S. Aromatic protons region of ${ }^{1} \mathrm{H}$ NMR spectrum of 9 in $\mathrm{D}_{2} \mathrm{O}, 25 \mathrm{mM} \mathrm{KH_{2 }} \mathrm{PO}_{4}, 150 \mathrm{mM}$ $\mathrm{KCl}$ and $1 \mathrm{mM}$ EDTA, $\mathrm{pH} 6.7,25^{\circ} \mathrm{C}$. 


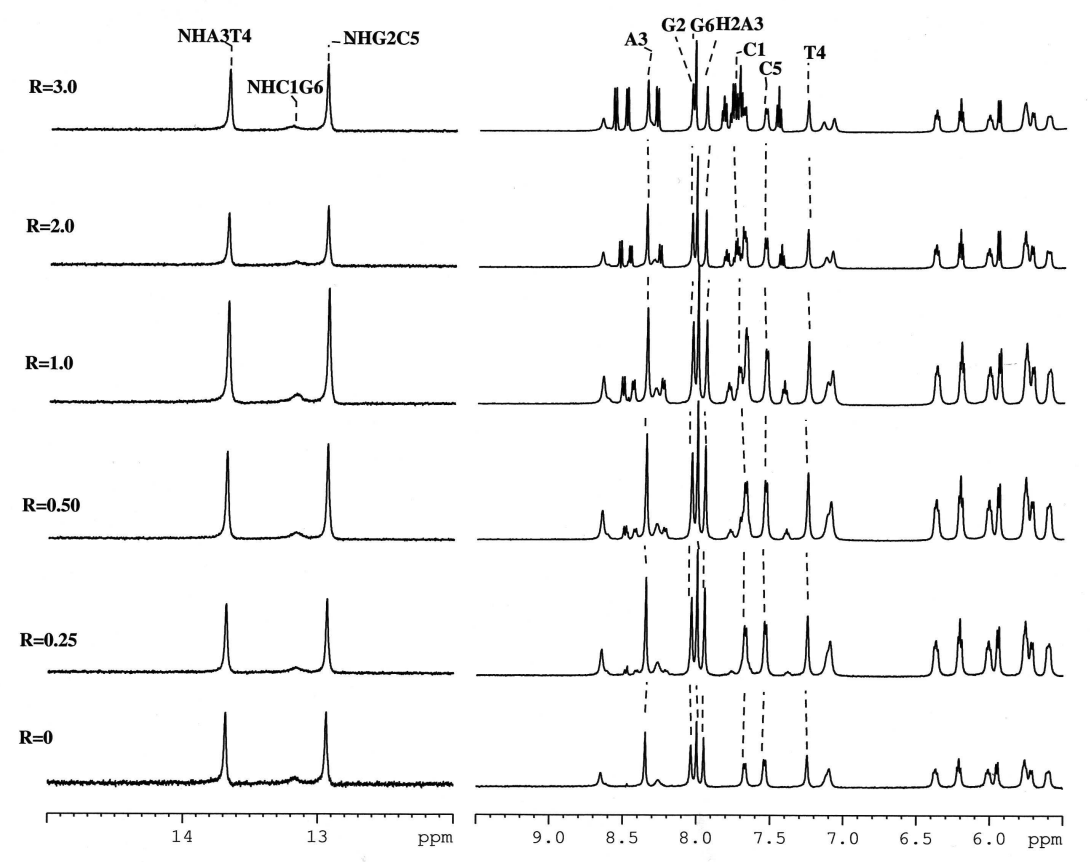

Figure 4S. Imino and aromatic protons region of ${ }^{1} \mathrm{H}$ NMR spectra of (CGATCG) $)_{2} / 3$ complex in $\mathrm{H}_{2} \mathrm{O}, 10 \mathrm{mM} \mathrm{KH}{ }_{2} \mathrm{PO}_{4}, 70 \mathrm{mM} \mathrm{KCl}$ and $0.2 \mathrm{mM}$ EDTA $(\mathrm{pH} 7.0), 15^{\circ} \mathrm{C}$ at different $\mathrm{R}=[3] /[$ $(\mathrm{CGATCG})_{2}$. 